\title{
Legitimacy, Identity, Violence and The Law
}

\author{
Michael Hatfield,Texas Tech University
}

I was surprised the Americans would do such a thing.

It shocked me.

Jamil El Banna, Guantánamo Bay detainee ${ }^{1}$

\section{The Shock of American Torture}

THE WORLD NOW KNOWS that Americans have been torturing individuals in America's care. These are no mere incidents of war. International law accepts that innocents will be unintentionally maimed and mutilated. But it does not permit those in the care of a nation to be intentionally maimed and mutilated. Nevertheless, intentional maiming and mutilating by Americans has spread from Cuba and Afghanistan to Iraq and, perhaps, elsewhere.

Torture is prohibited by the Universal Declaration of Human Rights, the International Covenant on Civil and Political Rights, the Convention Against Torture and Other Cruel, Inhuman, Degrading Treatment or Punishment, and the Geneva Conventions. However, the prohibition of torture is so fundamental to the international order, it does not need to be contained in one of these agreements in order to have the force of law. In international law, it is a preemptory legal norm no state is free to contravene. It is part of the obligations that every state owes to all other states by virtue of being a legitimate member of the international community. ${ }^{2}$

The United States has enacted its own laws to implement this internationally-imposed obligation. Under domestic American law, Americans torturing (or attempting to torture or conspiring to torture) outside of the United States can be punished by imprisonment or, if the victim dies, the death penalty. ${ }^{3}$

Despite the illegality of torture, the United States government's position has been that none of the barbaric acts are "torture" in any legally prohibited sense. It has claimed that what is clearly torture by any moral standard is not torture under American legal standards. The global moral consensus likely would have accepted isolated acts of torture. What can- 
not be accepted, however, is the claim of legality. By refusing to submit its law to international standards, the United States has established that its only limit on the world stage will be its military power.

\title{
Civilization and Its Definitions
}

\begin{abstract}
America's idea of what is torture is not the same as ours and does not appear to coincide with that of most civilised nations.
\end{abstract}

The Honorable Mr Justice Lawrence Collins, Her Majesty's High Court of Justice ${ }^{4}$

Before the physical torture, there were lawyers who advised the American government that it could proceed to torture without legal culpability. Lawyers with treatises and statutes and dictionaries piled high on their desks convinced themselves that torture was not "torture." Their reasoning was recorded in the now infamous August 1, 2002 "torture memo" signed by then-Assistant Attorney General Jay S. Bybee. ${ }^{6}$ The torture memo provided legal advice regarding standards of conduct for interrogation under American law. Ignoring binding legal authority and all arguments to the contrary, the lawyers concluded that no interrogation technique fits the definition of "torture" unless the victim feels pain akin in severity to death or organ failure but that, even then, the President of the United States could legally order such interrogation techniques as the choice of the lesser evil: harming a single individual in order to prevent further terrorist attacks.

It is difficult to believe the memorandum was written in a good faith attempt to constrain behavior. After all, legal culpability for torture is quite easily avoided by refusing to intentionally maim and mutilate those in your care. As with laws against rape, battery, arson, and abduction, the international laws against torture were drafted to buttress undeniable moral norms. Unlike laws on wills, trusts, corporations and tax, the laws were not intended to facilitate planning. And it is difficult to believe a detailed memorandum was necessary to comply with the law. Our moral intuition to avoid intentionally inflicting pain is itself sufficient to avoid criminal liability for torture - just as it is to avoid criminal liability for wife beating, murder, and child molesting.

The legal permission in the torture memorandum seems more likely an attempt to avoid a personal sense of moral responsibility. Those involved in torture have been known to seek out religious permission, religious assurances that they are not moral monsters. Being granted these assurances, individuals who are not usually vicious or sadistic accept their 
role as torturers. ${ }^{7}$ Humans have an immense ability to inflict cruelty. However, we have a very limited ability to believe ourselves to be cruel. Perhaps this was at the root of seeking legal advice. When the torturer believes that he has been authorized by the larger demands of goodness to torture, he is then no longer personally responsible. He becomes but an agent of a greater, exceptional moral cause.

Through the torture memo, the government lawyers provided the means by which someone (directly or indirectly) guilty of torture could hide it from himself. Under these special circumstances of legal advice, the torturer need not consider himself a moral monster even if he acts monstrously by all other standards he knows. That is, when the lawyer gave the legal authority to the actor with practical authority, the lawyer made the law into the author of the actor's actions. It was the law that became responsible for allowing what it does rather than the torturer being responsible for doing what it is he did. Thus, the torturer does not have to believe he is cruel or immoral. He is a deputized agent of the law's wisdom.

The government lawyers spoke on behalf of a higher authority, the law. It was not their personal endorsement of the morally suspect that was needed but rather the conclusion that the law endorses it. With ample opportunity for American citizens to affect the democratic law-making process, it is no misuse of language to equate the American law with the collective American will. Thus, with the torturer's reliance on the lawyer's advice, his self-understanding is that he is the agent of the American people - entrusted with this power for their protection.

\section{Decreasing Legitimacy By Decreasing Self-Limits}

The stories they told were remarkably similar-terrible beatings, hung from the wrists and beaten, removal of clothing, hooding, exposure naked to extreme cold, naked in front of female guards, sexual taunting by both male and female guards/interrogators, some sexual abuse (rectal intrusion), terrible uncomfortable positions for hours. ${ }^{8}$

Notes of an American lawyer after meeting with Guantánamo Bay detainees

While not pristine, the United States' relatively good historical deference to moral and legal limits on its power has maintained its political legitimacy. Now, however, the United States' torture of those in its care has made it increasingly difficult for it to leverage moral authority into political power. Even though the law is insufficient to prevent torture, the 
international legal prohibition of torture is not impractical. As with all malum in se crimes, ${ }^{9}$ the law's power is not so much a deterrent. More importantly, this deference to morality is each state's means of identifying its power as moral and not merely actual. It is a state's sacrifice to a standard other than its actual power-a moral standard. It represents the state's voluntary will to limit its power in the light of morality. It is a sine qua non of the state's political legitimacy insofar as the state has to convince others that it accepts normative limits and not just physical limits.

The fact that America is a relatively functional democracy makes the matter much worse. Those tortured, their friends and family members, and all the other members of the international community are entitled to infer that if American law permits torture, it is because the American people want it this way. From this perspective, it was not only the United States government at fault but Americans themselves. The same dynamics that allow the legal advice to comfort an American torturer are at work here as well. If the American lawyer's advice is that torture is permissible under American law and can be used because the American people have entrusted their leaders with this legal power, then it is the American people — and not just a handful of rogue sadists - whose will is at work.

The law in a democracy matters because it reflects how the citizens choose to define themselves and their relationship to history, how it is they explain themselves to others. The law in a democracy is the citizens' means of communicating what type of nation they intend theirs to be. Our laws fix our identity - for ourselves, our children, our friends, and our enemies.

The laws of a nation are its idealized identity. Political legitimacy notes the idealized identity but also the distance between the ideal and the actual. Many nations have idealized identities of democracy and freedom without any actual realization of either. They have statutes comprised of written rights actually denied in the workplaces, streets, prisons and court rooms. In a democracy such as the United States, however, the people are morally responsible for this idealized vision of themselves. A claim that the laws permit the morally prohibited is a claim about the moral identity of Americans, not rogue leadership.

The argument as to whether or not American laws do in fact permit morally prohibited torture is an argument about America's self-chosen identity. If the legal interpretations claimed by the United States government are not a reliable construction of American law, then Americans can blame their leadership for acting illegally. This may do much or little 
to help to prevent future torture. However, it is essential in the struggle between Americans to choose who we shall be as a people, to choose and defend our identity. A visible struggle among Americans on this issue will play a large part in the international assessment of American legitimacy. This struggle over how to interpret the law is a struggle for national moral identity.

\section{Who Is For Torture?}

Make no mistake: Every regime that tortures does so in the name of salvation, some superior goal, some promise of paradise. Call it communism, call it the free market, call it the free world, call it the national interest, call it fascism, call it the leader, call it civilization, call it the service of God, call it the need for information, call it what you will, the cost of paradise, the promise of some sort of paradise, Ivan Karamazov continues to whisper to us, will always be hell for at least one person somewhere, sometime. ${ }^{10}$

Ariel Dorfman, Chilean novelist, essayist, playwright and human rights activist

The belief that maiming and twisting and breaking human minds and bodies is supposed to safeguard our well-being arises from the darkest depths of human confusion. The conclusion that torture is appropriate can be reached only by ignoring not only human dignity but our human inabilities, uncertainties, and untrustworthiness. These all combine to make torture an inherently unmanageable form of violence that ultimately destroys those who use it. Torture is a modern taboo. It is illegal for good reason.

So, how could American lawyers convince themselves it is legal?

The first step in arguing torture is legal is to exclude the history and purpose of the relevant legal standards and focus only on specific words in texts. Manipulating the tension between the specific words and the general purpose of a legal rule is a well worn legal reasoning technique. Typically, the more tightly focused on specific definitions, the more technical, legalistic, and aggressive the argument is. This technique allows the lawyer to narrow the definition of torture so as to expand its use. ${ }^{11}$ The argument does not authorize "torture," of course, since "torture" is illegal. Rather, the argument authorizes coercive interrogation techniques, sorting into this category various acts of torture that are not "torture." This is lawyering as euphemism-engineering.

A second lawyering technique is used as a back-up in case the line between torture and "torture" is later determined not to be quite where 
the lawyer drew it. The technique is to appeal to utilitarian moral reasoning. This is why the legal discussions of torture often read like a college freshman's paper in philosophy 101. Lawyers such as Jay S. Bybee appeal to utilitarianism with a simple "lesser-of-two-evils" argument that invokes the criminal defense of necessity. ${ }^{12}$ Other lawyers are sufficiently confident to express an explicitly utilitarian formula complete with symbols such as " $\mathrm{L}=$ the number of lives that will be lost if the information is not provided" and " $\mathrm{T}=$ the time available before the disaster will occur" and directions that "torture should be permitted where the application of the variables exceeds ... the numerical point at which torture is acceptable." 13 But unlike the philosophy 101 hypotheticals that are intended to refine the student's moral sense, these formulae are intended to facilitate the legal expansion of torture. Also unlike philosophy 101, in which the philosophy professor's political powers are benign, these lawyers integrate rote philosophy 101 arguments into legal interpretations in order to direct state power. Whatever the lawyers lack in philosophical sophistication and grace, they make up for in access to state power, which they are now using in a real-world experiment.

The lawyers ignore that utilitarian reasoning requires a considerable amount of certainty as to the consequences of actions. They ignore the fact that there is no reliable source for the empirical data needed to make the utilitarian arguments they make. The proponents have to invoke some secret reserve of classified information as to the prevalence of ticking time bomb-type scenarios that we are supposed to believe are rather common. Ultimately, the resort has to be to a "trust me" on the facts.

Not only does the pro-torture, lesser-of-two evils, lawyering approach rely on information that does not exist, it ignores the information that does. Much about the American abuses seems calculated more to satisfy sexualized interests or pure sadism than to elicit reliable information. Even if torture could be justified with a ticking time bomb scenario, we know it has not been limited to those scenarios. And even if it has provided information relevant to international security, we know that the international outrage at American torture has fueled resentment and violence and made us all less secure rather than more secure. Fear of the moral slippery slope was not invented in a classroom but through historical reflection. Torture never happens just once or only in isolated instances. Yet somehow this well-known information is never part of the consequence-analysis the argument calls for, while all varieties of speculative or secret information are essential to it.

Torture, thus, gets legalized under these interpretations by insisting on excessively technical statutory readings; ignoring the moral and 
historical contexts in favor of the pseudo-scientific appeal of utilitarian calculus; and invoking unverifiable information while dismissing facts that are known world-wide. What connects these strategies is the rhetorical appeal to language that involves precise terms and mathematics-like certainty and objectivity.

This rhetorical style ensures that there is no appeal to anything more fundamental than the words describing the law, except the need to secure the nation. It is an argument about survival on any terms as the undeniable good served by the lesser of any two evils. Rather than appealing to moral principles, it alleges facts. Its language is technical. Rhetorically, it is a campaign against naiveté, and the confident precision of its terms is part of its persuasiveness. Its rhetorical demands are seriousness and sobriety about the situation. It is wholly indifferent to human rights principles, which are rejected as utterly unsuited for the present debate even though they are the principles that ground the American legal system. However, as of September 11, these legal principles and those who propose them are deemed effete.

The style also reveals something about those who use it. It presents the law in mechanical, technical terms suggesting the law is a machine. This justifies the cold tone since a machine is not swayable by appeals to human dignity. The machine marches on its programmed tracks. It presents the lawyer's job as an objective one: describing the track the machine is on and when it can be expected to arrive at which station. More deeply, this rhetorical style insulates the lawyer from any personal responsibility for his work. It gives the lawyer a self-perceived defense of "obeying orders," which does not work for soldiers but is expected to work for lawyers who give the ultimate endorsement to the soldiers' torturing. It presents the lawyer as just doing his job, reporting the facts and nothing but the facts as to what the law requires. It provides to the lawyer the same cover for moral guilt that the torturer seeks when he asks for the lawyer's blessing: the lawyer is no moral monster for opining that torture is legal but rather is only the sober technician carrying-out his job. ${ }^{14}$

\section{ViolenCE AND JURISPRUDENCE}

Legal interpretation is (1) a practical activity, (2) designed to generate credible threats and actual deeds of violence, (3) in an effective way. . . Legal interpretation, therefore, can never be 'free; 'it can never be the function of an understanding of the text or word alone.

Robert M. Cover, Chancellor Kent Professor of Law and Legal History, Yale University ${ }^{15}$ 
It is demoralizing for American lawyers to be revisiting the legality of torture. It is scandalous that individuals can be trained and practice as lawyers and rise in the professional ranks to the places from which they can advise the President and still have the impression that torture could be legal so long as it is called something else. It is as shocking as if slavery had been legalized simply by calling it "permanent employment." Of all the issues one might have recently thought well-settled into the dustbin of legal history, the prohibition of torture was certainly one.

For all its shamefulness, the topic is useful for reflecting on our understanding of the law and lawyers' relationships to it. Though our energies as lawyers would be better employed in devising methods to implement the prohibition, for the time being they have been derailed into justifying the prohibition. Nevertheless, having to take stock of ourselves on such a basic issue provides us with a good perspective for pondering basic issues, far more useful than beginning with speculations as to the inner workings of judges' or legislators' minds or the nature of language or society.

The legality or illegality of torture focuses our attention on the connection between law and violence. This connection is always there. Reducing, managing, controlling violence is the genesis of the law. The law organizes the threat of violence into predictable patterns. When a judge decides that this or that person is guilty or this or that will is invalid or this or that corporation shall win or lose its day in court, the judge has decreed that the state may bring violence upon the situation to take property in one person's possession and give it to another or, in criminal cases, to put someone in someone else's possession. Every dispute about the law is a dispute as to who shall be subjected to the state's threat of violence and who shall benefit from it. By the very nature of the craft, legal interpretation always takes place in a field of potential violence. ${ }^{16}$ The law substitutes just and reasonable violence for idiosyncratic, unjustifiable violence. Torture as a specific legal question raises the general question as to the ways in which violence is managed by the law. It is the question of how official violence is to be channeled, organized, and brought to bear on an individual in pursuit of some greater collective good.

What kind of violence does American law channel, organize and manage? The torture prohibition is emblematic of the commitment of the law to non-brutality. It is not simply a rule. It is, in the words of Jeremy Waldron of New York University School of Law, an icon of the whole law, an archetype. ${ }^{17}$ As such, it represents, embodies, and reflects something shared by every part of the American legal system and is not just the feature of this or that particular statute. It is a commitment that 
the law shall not wield its power through "abject fear and terror." ${ }^{\text {"18 }}$ It is a commitment to recognizing human dignity.

The relationship of violence to the legal need to prohibit torture reflects something even more fundamental about the legal system: how the system's legitimacy is eventually tested. The legitimacy of a legal system is not simply a product of its insiders and how they assess the persuasiveness of this or that legal argument. Legitimacy is something conferred from outside the system by all those affected by it, rather than something guarded by insiders who control it. A sense by outsiders that the legal system is losing legitimacy raises the risk of unmanaged violence, and managing the risk of violence is the purpose of the legal system. Ultimately, lawyers are kept in check not by their mutual assurances as to the appropriateness of their legal reasoning but rather by the threat that laws considered unjust by those outside the legal guild ultimately increase violence. This increased violence is inherently revolutionary, always threatening to overthrow both the system and its protective guild - perhaps slowly, perhaps suddenly. With the claims of legality attached to American torture, the decrease in the international assessment of American political legitimacy is also a decrease in the legitimacy of the American legal system, each decrease increasing the risk of violence.

\section{Footnotes to Torture}

Not since the Nazi era have so many lawyers been so clearly involved in international crimes concerning the treatment and interrogation of persons detained during war. ${ }^{19}$

Jordan J. Paust, Law Foundation Professor, University of Houston; Former Judge Advocate General Corps Lawyer, United States Army

While the popular perception of lawyers tends to be one of a courtroom actor, and legal theorizers tend to imagine the lawyer as judge, the resurrection of torture as a legal issue shifts the analysis from these showier roles to the quieter, often invisible role of the lawyer as office advisor. It was neither courtroom drama nor judicial intervention that led to torture being deemed legal under American standards. It was the lowly legal opinion memorandum.

The legal opinion memorandum is the method by which office lawyers advise their clients, though they are really doing more to advise themselves. Other than its conclusion-reduced to a go or a stop to the 
client's plans - a written legal opinion is not really addressed to the client. Unlike the boisterous courtroom arguments of litigators persuading judges and juries, a written opinion is a quiet stringing-together of definitions to persuade the opinion's author. It is the professional's research paper filed away to remind him at any future time how it was he decided to say yes to his client. It is an introverted product of the profession's more introverted wordsmiths, differing little from any academic essay in the humanities except that it is intended to provide a map for targeting or evading the violence of the legal system in the client's favor, should the need ever arise. Fortunes and liberties are traded on the backs of these essays, as clients wager this way or that based on their faith in the lawyer's cleverness. The lawyer is well-paid for the cleverness in justifying a foregone conclusion or, at least, justifying something substantially similar in practical terms.

For the most part, legal opinion memoranda and the office lawyers who write them remain outside of popular awareness, but their memoranda have substantial consequences in the legal system. Clients rely on the conclusions, which means that clients take action based on them. For the vast majority of memoranda, there is never a day of doctrinal reckoning. They remain filed away. It is only when the client collides with an adversary or a regulator that someone searches the files to find the legal map, and only when the collision gets to - or at least near - a courtroom that the memorandum's theories are tested. The functional audit rate, so to speak, of memoranda is so low that both lawyers and clients can carry on for years without the legal reasoning being tested. This roulette dynamic can encourage lawyers to adopt ever more aggressive and idiosyncratic lines of reasoning, and can provide the clients with an increasingly unwarranted sense of confidence. Almost all legal opinions result in client action, but very few of them are ever tested doctrinally.

If our understanding of the law begins with the courtroom arguments rather than the office memoranda, we envision a competition between two interpretations of the law. We then analyze the outcome of that competitive process and what tends to make it more or less reliable. This usually leads to analyzing the role of the judge as the relevant decision maker, and this leads to analyzing the professional norms of persuasiveness and both legitimate and illegitimate judicial biases.

The torture memorandum, however, directs our attention to the lessertheorized and more common mode of legal decision making. Rather than two lawyers publicly in front of a judge, we see a lawyer privately with a client. The client talks a while, and then the lawyer talks a while. These conversations remain protected from public scrutiny. If the con- 
versations conclude with the need for a legal memorandum, the lawyer fills the desktop with books and the pot with coffee, shuts the doors and begins the work of persuading himself how he might one day publicly champion what his client has privately told him the client intends to do. Unlike the litigator-based model of legal philosophy, this model has no single decision maker and certainly no impartial one. Rather this model involves a lawyer and client negotiating between themselves what risks either or both of them are willing to take. The client's risks may be property or freedom, while the lawyer's risk is one of reputation and malpractice suits.

Unlike the litigation model of lawyering, in the office model of lawyering the legal advice is one of the first links in the chain of causation. While a courtroom lawyer's interpretation of the law is an ex post facto prosecution or defense, the office lawyer's memo interpretation is one intended to give birth to certain facts - the client's behavior in relying on it. The American government memorandum that torture is not "torture" was not an argument in a court to defend someone from prosecution for "torture." Rather, it was permission to torture. Unlike courtroom arguments, legal opinion memoranda of this sort are seeds for future action. And it is the lawyer who chooses how best to sow what the client hopes to reap.

\section{Political Conclusions and Professional Arguments}

Nagem Sadun Hatab, a 52 year old Iraqi, died in US custody on 6 June 2003 in Nasiriya, Iraq, as a result of "asphyxia due to strangulation." The autopsy also found bruising and six fractured ribs. Army investigators said that he had been kicked by soldiers on 4 June. The next day he was reportedly lethargic and covered in feces. The jail commander ordered that he be stripped and he was left naked outside in the sun and heat for the rest of the day and into the night..$^{20}$

Amnesty International Report

Legal opinion writing involves the lawyer's whole personality, not just a textual skill set. It involves the lawyer's risk-aversion, the lawyer's understanding of the client, the client's objectives, and the client's riskaversion. It involves the lawyer's political understanding of the relationship of the client to governmental constraint; that is, the law. It involves the lawyer's moral sense that both the client and the client's objectives are consistent with the lawyer's values. It involves the lawyer's understanding of public policies. Ultimately, whatever forces are at play are 
brought to bear on a handful of legal interpretations devised by the lawyer to persuade the lawyer that the client can or cannot proceed.

The lawyer's interpretation of the law is how the lawyer votes for what the law is to mean. The legal system is closed in that only those admitted into the guild are given the right to have their votes heard. Only a lawyer's opinion on the law counts. Anon-lawyer and a lawyer may have the same arguments and the same conclusions, but the non-lawyer is not permitted to voice them either in private with a client or in public with a judge. All of the similarities a legal opinion has to humanities essays come to an end this way: the lawyer's conclusions matter in a specific way that no one else's does. Even in a democracy, only the citizens vote.

Much as America's being democratic means Americans are accountable for their laws in a way in which citizens of non-democratic nations cannot be, American lawyers must be held accountable. Whatever level of responsibility Americans generally share for American law, American lawyers share a greater responsibility as they are the ones with the exclusive occupational right to voice or ignore the law. The international community should pressure Americans for failing to eliminate torture in their name. And American citizens should pressure American lawyers to eliminate torture from their interpretations. The lawyers decide what the law requires or prohibits. It is lawyers who opined that torture was not "torture." And with those legal opinions, seeds for future state behavior were sown. True enough, those legal opinions were not sufficient for torture. But they were necessary for the legitimacy-destroying claim that American torture was legal.

The ability to control, even if not unfettered, confers moral responsibility. Lawyers have exclusive control of legal interpretation. We cannot pretend, if we ever could, that lawyers interpret the law for their client the way one interprets a foreign language for one who does not know it. Lawyers construct legal interpretations with all sorts of conscious and unconscious personal assessments, and are morally responsible for what follows when someone acts upon their interpretation.

This claim of moral responsibility is more radical than it might at first seem. It means that the lawyer is not the mere messenger of the law. However, the legal profession is designed on the premise that the lawyer is the mere messenger of the law. Alegal wall of responsibility is erected between the lawyer and client. The lawyer is not responsible for the client's objectives, only to ensure that the client is advised on how best to legally pursue them. But the torture memorandum makes clear that the condition of "how best to legally pursue them" is not much of a constraint. In practice and in critical theory, the lawyer's skills to expand 
or contract what can be "legally pursued" are well known. Those skills are also well compensated. Yet, the wall separating the lawyer's and the client's moral identities theoretically remains.

The lawyer's exclusive occupational right to interpret the law ought to imply more than moral responsibility. And in some situations it does. Powerful and wealthy clients know that if they rely on the lawyer's legal opinions and suffer some sort of loss, they can be made whole by suing the lawyer for malpractice. These clients understand that the lawyer is wagering with legal interpretations, and they are sufficiently sophisticated to make sure the lawyer's bets are backed with the lawyer's own wealth rather than theirs. They insure their reliance on the lawyer's advice with the lawyer's assets. If they follow the advice and lose money, they take the money from the lawyer (or the lawyer's malpractice insurance provider, as the case may be).

Despite the fact that sophisticated legal clients know-and rely on - the potential personal liability of the lawyer when assessing the lawyer's legal interpretations, claims for making lawyers personally liable for their legal interpretations are understandably disfavored by the lawyers' guild. At most, the guild permits a lawyer to be liable for technical deficiencies in interpretation, that is, for failing to cite this or that authority or to recognize this or that distinction between the authorities cited. For example, even though Judge Jay S. Bybee has been overwhelmingly criticized by the American bar for his torture memorandum - with a former dean of Yale Law School calling it "the most clearly erroneous legal opinion I have ever read"21 — the vilest punishment proposed for him is removal from the guild, disbarment, being stripped of the right to make a six figure annual salary. ${ }^{22}$ If, under American law, a soldier can be executed for torturing a victim to death, why not execute the lawyer who gives permission to torture?

Suggesting that lawyers might be imprisoned or executed for endorsing torture is more than an appeal to rough justice. It is grasping for some means to reign in the advice that American lawyers give when they know their advice will be acted on. This is not about prosecuting a lawyer who has defended a torturer. It is about prosecuting a lawyer who has consciously persuaded himself that torture was not "torture," knowing that once he had persuaded himself then someone was quite likely to be tortured.

Other than forcing lawyers into the same risks of those they advise, how can we force lawyers to use the best of all their personal resources and energies when interpreting the law, rather than hiding behind a fictional separation between themselves and their interpretation? How do 
we force lawyers to integrate more rather than fewer of their faculties into their reasoning? How do we force lawyers to give the best advice they can, other than putting them into the situation in which they are advising themselves? The advice we want lawyers to give is the description of what they would do if they were put in the client's situation with exactly the same risks of loss and punishment. How do we enforce moral responsibility for legal opinions? How do we force lawyers to respect the law? What is the safety net?

If a lawyer would not asphyxiate a detainee, then he ought not to give permission for someone else to do so. If a tax lawyer can lose her life savings for erroneously interpreting the intricacies of the tax code for a wealthy client, ought we to object to imprisoning a lawyer for erroneously claiming the American law endorses torture?

This empties the notion of professional and personal separation. But the division between the two has grown so great that there appears to be nothing some American lawyer somewhere would not be willing to advise as legal. Indeed, the division has grown so great that very powerful American lawyers advising the American President have opined that torture itself is legal so long as it is given another name. At what point of moral outrage over the disconnect between professional and personal separation do we question the consequences of the disconnect? What else would have kept American lawyers from advising that torture was legal? How else can American lawyers be forced to internalize the risks of their legal interpretations?

If we reject claims of the image of a law as a machine and lawyering as an objective job for a technician, we must also reject the separation between the professional and personal. To tweak the slogan: the professional is political. Our personal judgments as to the morality of torture are what drive our professional conclusions as to its legality. Ultimately, then, we must admit that any professional debate is political. It's those who categorically oppose torture struggling professionally against those who would permit it in our names, at least sometimes, at least in the scariest of situations, at least when it is in our best interests as determined by the governmental interrogation apparatus.

The ultimate question for each lawyer is, AmI willing to be an officer of a legal system that endorses torture? If not, I am obligated to argue that torture is illegal. Just as Americans struggle to preserve the international political legitimacy of the United States by struggling to make clear that we as a people do not condone torture, American lawyers must struggle to preserve the legitimacy of our legal system by insisting that it not legalize torture no matter what it is called. 
We cannot abide the defense that a soldier was just obeying orders. We cannot abide a lawyer's claim that the conclusion endorsing the morally horrific resulted from obeying the orders of a law impervious to morality. No lawyer believes the lawyer's job is simply reporting the facts and nothing but the facts as to what the law requires. We cannot provide cover for the guilty by continuing to defend a separation between the professional opinion of the lawyer and the lawyer. Lawyers who endorse torture ought to be prosecutable for torture consequent to their endorsement. This is not a tricky issue. Just as no one has a legitimate reason to know where on the continuum an intrusion one degree short of rape may be found, there is no legitimate reason for a lawyer to draw legal distinctions along the continuum of maiming and mutilating defenseless men and women in American care. Any lawyer doing so should personally assume the risk of error. The chilling caution of strict liability seems especially appropriate. ${ }^{23}$

\section{Moral and Legal Absolutes}

I say that to take the straight beautiful bodies of men and women and to maim and mutilate them by torture is a crime against high heaven and the holy spirit of man. I say that it is a sin against the Holy Ghost for which there is no forgiveness. ${ }^{24}$

Mr. F.S. Cocks, United Kingdom delegate urging the adoption of the 1950 European Convention on Human Rights

So long as we refuse to accept the legal legitimacy of the lesser-oftwo-evils moral analysis of torture, we are taking an absolutist position. Without invoking religious or metaphysical ideas, we are left appealing to preserving human dignity without being able to argue non-circularly as to what "human dignity" is. That may be fine. That may be as far as we can think about it. We may need to say that we can reduce the idea to nothing simpler, nothing more persuasive. But we need to be content with that. We ought not to be tempted to search for empirically conclusive grounding for our claims because none will ever be established. We cannot, for example, rest our moral conclusion against torture on the unverifiable claim that it never produces information that could save lives. We cannot assume the prohibition of torture does not have some costs. ${ }^{25}$ This is not to say that we ought not to marshal factual evidence that torture increases violence rather than decreases it, but that we ought to accept that the essence of moral claims is a wagering as to which way is the best way forward. A wagering that reflects as much evidence as 
there might be, but a type of judgment that always involves a material degree of uncertainty. We do not have the luxury of awaiting empirical assurances. We are forced to decide with some doubt as to what the future will bring as a result of our moral decisions. We may believe it is obvious that respecting human dignity decreases violence across time. But we must admit that this is our moral hope, not an empirical conclusion. This is a hope involving a conscious choice of moral identity and not a reporting of empirically verifiable claims.

Legal absolutes are even more problematic than moral ones. The law never maps perfectly onto morality, and for good reason. For one, unlike moral theories, the law must not only be concerned with articulating standards but also devising consequences for transgressions. It must define degrees of culpability, codify extenuating circumstances, and institutionalize mercy for the guilty and not just sympathy for the victim. The current parade of American soldiers charged with abuses and the absence of charges against higher authorities also reminds us that guilt may be shared and often unequally so.

Just as we accept self-defense as an excuse for killing while prohibiting murder categorically, as a legal matter we must accept some defenses for individuals who torture. ${ }^{26}$ These types of defenses, however, can be transformed into a systematic approval of torture, if we let them. It is one type of claim to defend a confused soldier who intentionally maimed a particular prisoner for what seemed a good reason at the time, and another type of claim that there is good reason for an army to systematically maim prisoners. We must remember that the essence of defensive justifications of violence is that they cannot be premeditated but rather always involve a sense of acting-in-the-moment, a denial of time or opportunity for reflection or devising a less violent response. Indeed, only the least degree of useful violence can ever be justified defensively.

These are the factors missing from the United States government's endorsement of torture as the lesser-of-two-evils in its war on terrorism. The government lawyers' torture memo transformed a defensive plea of self-defense and necessity - the lesser-of-two-evils defense - into an offensive strategy. The detailed analysis approving torture was a premeditation, an advance rationalization of wholesale violence that appealed to the narrow criminal defense legally available for individuals acting in the heat of immediate moral confusion. This does not make the defense wrong. It means the torture memo was wrong.

There is a lurking question here: if certain extenuating circumstances may defend an individual from the criminal charges of torture, why limit those circumstances to ones involving immediate moral pressures 
and confusion? Wouldn't we better off allowing a systematic analysis? Wouldn't the individual soldier be better off knowing that the evils had already been weighed and calculated? Of what help is it to the individual to be pushed into the inconsistency of legally prohibiting torture but allowing narrow legal defenses to it? Wouldn't it be better to institutionally resolve the tensions between the absolute prohibition and the defensive authorization? After all, aren't we more likely to arrive at a better resolution when we do it that way - without pressure, institutionally, methodically - than when we force the individual into the heat of the moment?

This is the conclusion of those who advocate torture. What begins as institutionalizing mercy for the guilty who find themselves forced into unthinkable binds becomes the institutionalized endorsement of the unthinkable. This approach is the one taken by the United States government. The torture memorandum deferred to the President's moral calculations as to the lesser-of-two-evils, insisting he had the right to make these decisions on behalf of all Americans.

The law recognizes that humans find themselves in situations beyond their wisdom and beyond their abilities. The law cannot impose on an individual the obligation to risk being murdered by a midnight intruder rather than to resist with deadly force, nor can it impose an obligation that the individual interview the intruder as to his plans, weapons, and motivations prior to deciding whether or not to shoot him. The law compromises by respecting the imperfections of human abilities when responding to overwhelming situations. If it turns out the intruder was a harmless neighbor with dementia searching for his long-dead mother, the law forgives the killing just as it would if the intruder had been equipped to murder. Defenses for violent crimes recognize that reality forces us at times to make decisions beyond our limits. These are situations without time or other resources that would allow the weighing or other investigation of alternatives. These are defenses of despair, not calculation.

To institutionalize a torture-approval process, however, is to apply all of the institution's abilities in the calculation of whom to torture. This is not a situation involving a pre-rational, biologically-based response of fear, panic, or defense, but rather an institutionalized rationalization. This is not a situation in which alternatives cannot be investigated, but rather a process of weighing alternatives. This is not a begrudging acceptance that the world forces individuals into inhuman choices, but rather the intentional creation of inhumane situations. The legitimate defenses to individual criminal charges are based on limits that inhere in individuals but are not found when there is ample time for group reflection and response. 
To return to the prior suggestion, the question is which legal approach do we believe will lead to lesser violence over the long term? On the one hand is a legal system that occasionally grants mercy to some sympathetic individual who in the heat of some inhumane situation intentionally maims another. On the other hand is a legal system that institutionalizes governmental resources in a process of deciding which individuals are to be intentionally maimed. The difference between granting mercy to the guilty and permission to the guilty is the difference between respecting and violating human dignity. This is the difference between the two approaches. Over the long run, it is hard to believe that the first approach generates more violence but harder to believe that the second approach does not. The first approach belongs to a more legitimate legal system than the second precisely because it will lead to less rather than more violence. There is, of course, empirical uncertainty in this claim. There is no legal laboratory in which we can independently try the alternative laws and confidently conclude the results. This is the wager of moral decision. This is the choice of national identity chosen individually: on which side am I willing for us to err? From that choice flows the legal reasoning and, ultimately, the gamble that torture is more likely to destroy us than preserve us.

\section{NOTES}

1. Amnesty International Index. "Torture and Ill-Treatment in the "War on Terror"": ACT 40/14/2005 available at www.web.amnesty.org/library/print/ENGACT400142005 (last visited September 7, 2006).

2. For a discussion of the legal prohibitions of torture beyond those contained in written agreements, see, e.g., Robert K. Goldman, "Trivializing Torture: The Office Of Legal Counsel's 2002 Opinion Letter And International Law Against Torture." Human Rights Brief 12 No. 1 (2004) 1-4; Sanford Levinson, "Precommitment and Postcommitment": The Ban on Torture In The Wake Of September 11." Texas Law Review 81 (2003): 2013-2053.

3. 18 U.S.C. Section 2340 (2000).

4. Richard Norton-Taylor and Suzanne Goldenberg, "Judge's Anger at US Torture," Guardian Unlimited (February 17,2006) available at www.guardian.co.uk/guantanamo/ story $/ 0,1711833,00 . \mathrm{html}$ (last visited September 7, 2006).

5. Memorandum from Jay S. Bybee, Assistant Attorney Gen., to Alberto R. Gonzales, Counsel to the President (Aug. 1, 2002) (the "Torture Memo") available at www.humanrightsfirst.org/us_law/etn/gonzales/memos_dir/memo_20020801_JD_\%20Gonz_pdffse arch $=\% 22 j a y \% 20$ bybee $\% 20$ torture $\% 20$ memo\% 22 (last visited September 8, 2006).

6. Although Jay S. Bybee signed the memorandum, others were involved in drafting it. John Choon Yoo was substantially involved in the drafting of the memorandum. The addressee of the memo was Alberto Gonzales. After the memorandum was written, Bybee was appointed by the President to the U.S. Court of Appeals for the Ninth Circuit (the Senate confirmed him to this lifetime appointment within two months, though 
the memorandum was apparently unknown to members of the Senate at the time). Mr. Gonzales was appointed by the President to become the Attomey General of the United States. Professor Yoo returned to his position as a member of the faculty at Boalt Hall School of Law, University of California, Berkeley.

7. Levinson, "Precommitment and Postcommitment," 2013.

8. Amnesty International Index, "Torture and Ill-Treatment in the "War on Terror."

9. A criminal act that is malum in se is an act that is wrong in itself, an act that is "inherently and essentially evil" (e.g., murder). In contrast, a crime that is malum prohibitum is wrong merely because the law forbids it (e.g., driving violations).

10. Ariel Dorman, "Untying An Ethical Question On Torture-Happiness For All Is One Justification," San Francisco Chronicle (May 9, 2004) available at /www.sfgate. com/cgiin/article.cgi? $f=/ c / a / 2004 / 05 / 09 / I N G P D 6 F P 5 L 1 . D T L$ (last visited September 7, 2006).

11. For a technical criticism of the narrowing of the definition of "torture" in the Torture Memo in order to expandits use, see Louis-Philippe F. Rouillard, "Misinterpreting the Prohibition of Torture Under International Law: The Office of Legal Counsel Memorandum." American University International Law Review 21 (2005): 9-41. 23-30

12. "Torture Memo," 46. "Necessity" is a defense to criminal charges that alleges the accused was forced to act under duress and had no legally-sanctioned alternatives; for example, killing another in self defense.

13. Mirko Bagaric and Julie Clarke, "Not Enough Official Torture In The World? The Circumstances In Which Torture Is Morally Justifiable." University of San Francisco Law Review 39 (2005): 581-616.613-614

14. This "defense" is made explicitly by some. See, e.g., Eric Posner \& Adrian Vermeule, "A 'Torture' Memo and Its Tortuous Critics." Wall Street Journal, July 6, 2004: A22.

15. Robert M. Cover, "Violence and the Word." Yale Law Journal 95 (1983): $1601-1629.1611,1617$

16. Cover, "Violence and the Word," 1601.

17. Jeremy Waldron, "Torture and Positive Law: Jurisprudence For The White House." Columbia Law Review 105 (2005): 1681-1750. 1722-1723.

18. Waldron, "Torture and Positive Law: Jurisprudence For The White House," $1726-1727$.

19. Jordan J. Paust, "Executive Plans and Authorizations to Violate International Law Concerning Treatment and Interrogation of Detainees." Columbia Journal of Transnational Law. 43 (2005): 811-863. 811.

20. Amnesty International Index, "Torture and Ill-Treatment in the "War on Terror."

21. W. Bradley Wendel, "Legal Ethics and the Separation of Law and Morals." Cornell Law Review 91 (2005): 67-128. 68. Calling it a legal analysis of which no one "could be proud," on page 68 , Wendel cites several sources identifying not only ethical lapses but blatant incompetence in the preparation of the memo, such as the statement by Harold Hongju Koh, Dean, Yale Law School, that: "in my professional opinion, the August 1, 2002 OLC Memorandum is perhaps the most clearly erroneous legal opinion I have ever read," quoted in "Confirmation Hearing on the Nomination of Alberto R. Gonzales to be Attorney General of the United States Before the S. Comm. on the Judiciary," 109th Cong. 158 (2005), available at www. access.gpo.gov/congress/senate/senate 14 ch109.html (last visited September 8, 2006); Kathleen Clark \& Julie Mertus, "Torturing the Law: The Justice Department's Legal Contortions on Interrogation," Washington Post June 20, 
2004: B3 (criticizing "stunning legal contortions" in the memo); Adam Liptak, "Legal Scholars Criticize Memos on Torture," New York Times June 25, 2004: A14 (quoting Cass Sunstein's opinion that the legal analysis in the memos was "very low level, . . . very weak, embarrassingly weak, just short of reckless"); Ruth Wedgewood \& R. James Woolsey, Op-Ed., "Law and Torture," Wall Street Journal June 28, 2004: A10 (concluding that the memos "bend and twist to avoid any legal restrictions" on torture and ignore or misapply governing law).

22. See Richard L. Abel et al., "Lawyers'Statement on Bush Administration's Torture Memos," available at http://www.afj.org/spotlight/0804statement.pdf (last visited Feb. 2, 2006). See also Richard B. Bidler \& Detlev F. Vagts, "Speaking Law to Power: Lawyers and Torture," American Journal of International Law 98 (2004): 689; Marisa Lopez, "Professional Responsibility: Tortured Independence in the Office of Legal Counsel," Florida Law Review 57 (2005): 685-716.

23. Strict liability is a legal standard that imposes responsibility even when the accused has exercised the customary level of care. In tort law, it is applicable with respect to abnormally dangerous activities, such as possessing wild animals or explosives. In criminal law, it means that no "guilty" intention is required to commit the crime. For example, an adult having sex with a teenager under the age of consent is the crime of statutory rape even if the adult had no reason to believe the teenager was below the age of consent (in fact, even if the adult had been deceived into reasonably believing the teenager was an adult). The purpose of strict liability is to chill inherently dangerous, risky or destructive behavior. It is not a common legal standard, and has never applied as a standard of care in giving legal advice.

24. Waldron, "Torture and Positive Law," 1710.

25. Levinson, "Precommitment and Postcommitment," 2013, 2029; also see Bagaric and Clarke, "Not Enough Official Torture In The World?," 588-590.

26. See above, regarding necessity defenses to criminal charges. 